\title{
Biodegradation of Erythrosin B Dye by Paramorphic Neurospora crassa 74A
}

\author{
Gisele Jane de Jesus* Carlos Renato Corso, Adriana de Campos and Sandra Mara Martins \\ Franchetti \\ Faculdade de Ciências Biológicas e Ambientais; Universidade Federal da Grande Dourados; Rua Mozart \\ Calheiros, 1400; 79811-010; Dourados - MS - Brasil
}

\begin{abstract}
The present work used paramorphic forms of Neurospora crassa 74A to remove erythrosine. The fungus culture was grown in medium containing the dye, as only carbon source for 2 and $90 \mathrm{~h}$ of interaction. A washing process using distilled water isolated the cellular mass mycelia was dried for $12 \mathrm{~h}$ at $105^{\circ} \mathrm{C}$ and transformed in fine powder and analyzed in FTIR. The supernatant was analyzed through spectrophotometer UV-Vis and FTIR. Significant differences in the spectrum of UV-VIS and FTIR were observed between the control and the supernatant and between wall control and the walls colored by red, in FTIR for 2 and $90 \mathrm{~h}$. Some significant bands were modified, suggesting the possibility of enzymatic biodegradation in proportion to the time of contact between the dye and fungal biomass.
\end{abstract}

Key words: Biodegradation, FTIR, Neurospora crassa, Paramorphic, Erythrosin

\section{INTRODUCTION}

Some proposals for the effluent and water treatment exist in literature, amongst these, Performance of the constructed wetland system for the treatment of water from the Corumbataí River (Borges et al., 2008). The hypothesis that effluents treated through activated sludge process cause changes in nutrient biogeochemistry of receiving water bodies was investigated in Vieira creek, southern Brazil (Santos et al. 2008). Toxic compounds release represents serious environmental problems, due to their chemical composition, which usually involves aromatic rings, azoic bounds, amines and sulphonics groups. Textile effluents containing dyes show a slow biodegradation process (Jesus, 2002). The world's ever increasing population and progressive adoption of an industrial - based lifestyle has inevitably led to an increased anthropogenic impact on the biosphere. In textile production, opportunities exist for the release into the ecosystem of operation. These pollutants are produced in an effort to improve the human standard of living and fashion but ironically, their unplanned intrusion into the environment can reverse the same standard of living by impacting negatively on the environment (Lefebvre et al., 2005).

Adsorption and degradation of three synthetic dyes with representative chromophores (azo, anthraquinone and indigo) were investigated on living mycelium of white rot fungus, Trametes versicolor. The maximum adsorption capacity and

*Author for correspondence: giselejesus@ufgd.edu.br 
adsorption affinity of the dead and living fungal mycelia to the three dyes were measured and estimated by using the Langmuir model. Fungal mycelium was saturated by the dyes in one hour and its adsorption capacity was regenerated at different rates depending on dye structure and enzymes (Wang and Yu, 1998). The biodegradation and the discoloration of azoic dyes were investigated by Chu (2001).

A study evaluated Leprous florida to biodegrade red 40, a dye used in foods. Mycelia grown in nutrient-rich and poor liquid mediums were used in different concentrations of dye and with various $\mathrm{pH}$. Spectrophotometric readings indicated that the dye had biodegraded in concentrations of 1.10-5 and 2.10-5 mol.dm-3, with the best results obtained at a $\mathrm{pH}$ of 4.5. It was also found that the mycelia grown in both nutrient-rich and nutrientpoor media presented red 40 biodegrading activity (Espíndola et al., 2007).

Lefebvre et al. (2005) studied the bioremediation of Reactive Yellow KD-3G, Red reactive 24, Blue Cationic X-GRL as indicator in aqueous solution, achieved up to $90 \%$ of discoloration at 20-30 minutes of photolytic treatment. The biochemical oxygen demand (DOB) and total organic carbon (TOC) decreased. The photo-treatment association and biodegradation showed to be efficient in the color removal.

Biodegradation of triphenylmethane dyes by bacteria, actinomycetes, yeast and fungi have been discussed in detail by Azmi et al., (1998). The disadvantages of physical and chemical treatment process of dye wastewater have also been discussed. This group of dyes is toxic depending on the concentration used.

Phlebia tremellosa was used in the discoloration of 8-synthetic-dye $(200 \mathrm{mg} / \mathrm{L}), \quad$ achieving reduction higher than $96 \%$ within 14 days under stationary incubation conditions. Results indicated that black reazol was degraded by the fungus; however, the complete mineralization did not occur in the supernatant. The lacase activity also occurred in the supernatant, when the fungus was cultivated in the presence of an artificial textile effluent (Kirby et al., 2000).

Fungal cell wall, mainly composed of chitin, an $N$ acetyglucosamine polymer, is known to participate in heavy metal detoxification the studies revealed that the conformation of chitin did not alter after cadmium complexation (Bhanoori and Venkateswerlu, 2000).
Biochemical and biophysical studies with Neurospora crassa suggested that cellular defense against copper toxicity involved the binding of the metal ion to wall associated polyphenols. The growth of $N$. crassa in the presence of toxic amounts of copper $(0.63 \mathrm{nM})$ resulted in the formation of blue colored mycelia and cell walls wherein most of the copper was wall-associated. Thin layer chromatography and FTIR spectra of polyphenols isolated from blue cell confirmed the presence of nitrophenols. Inhibited nitrate utilization and enhanced tyrosinase activity, occurring under conditions of copper toxicity, seem to contribute to the formation of (poly) nitro - phenols on cell surface through simple physicochemical mechanisms catalyzed by copper (Suresh and Subramanyam, 1998).

A cellular growth of Azospirillum brasiliense, was observed, in the presence of high amounts of heavy metals. The structural analyses of the cells wall were obtained, together with results provided by the atomic absorbance chromatography (Kamnev et al., 1997). A new strain, exhibiting an intriguing pink-colored cell phenotype, was obtained after an encoding $\alpha$-glucosidase gene from an archaebacteria Thermococcus hydrothermalis was cloned by functional complementation. Modifications in the major components of cell wall did not jeopardize the cell viability. Such rapid optical spectroscopic method can be used to screen a wide range of yeast mutants (Galichet et al., 2001).

In this work paramorphogenic form of $N$. crassa was used for the removal and biodegradation of the Erythrosin B dye in aqueous solution, to verify the end of the biosorption and the beginning of the biodegradation, keeping the best conditions of the fungi culture.

\section{MATERIAL AND METHODS}

The paramorphogenic form of $N$. crassa was observed by following the method described by (Marcanti-Contato et al., (1997) and Tatum et al., (1949). After 24 hours, the pellets were ready to be submitted to biodegradation tests.

Azo dye Erythrosin B (Fig. 1) was put in contact with the fungus at an initial concentration of $100 \mu \mathrm{g} / \mathrm{mL}$ at $30^{\circ} \mathrm{C}$ during 2 and $90 \mathrm{~h}(\mathrm{pH} 4.5)$. After centrifuging $(3500 \mathrm{~g})$, the mycelium and the supernatant were spectrophotometrically analyzed. 
The $90 \mathrm{~h}$ was chosen as his maximum time the biomass was in state of decomposition.

The UV-Vis (Ultraviolet - Visible) and IV of the samples of the original dye and from the supernatant (post-treated) were analyzed, and the IV not colored the cell wall and the samples of the cellular walls with the observed dyes (biomass-dye and supernatant dye after drying with 2 and $90 \mathrm{~h}$ contact).

For the FTIR (Fourier transform infrared spectroscopy) analyses $\mathrm{KBr}$ capsule were prepared, that is the powder of the triturated cell wall was mixed (1mg) with fresh $\mathrm{KBr}(149 \mathrm{mg})$. This mixture was compacted during 5 minutes, at $30 \mathrm{Kn}$ pressure. The same treatment was preformed for the dye of the supernatant. The lecture range of IV was $4000-400 \mathrm{~cm}^{-1}$ and it was performed in IR FTIR, Shimadzu 8300, with a resolution of $4 \mathrm{~cm}^{-1}$. For the preparation of the supernatant capsule, $1.5 \mathrm{~mL}$ of the dye solution were collected and mixed in $3 \mathrm{mg}$ of $\mathrm{KBr}$, after that they were put in the stove at $105^{\circ} \mathrm{C}$ for $12 \mathrm{~h}$.

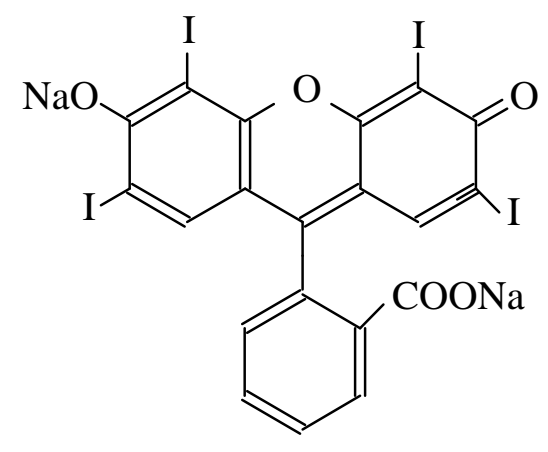

Figure 1 - The Structure of the Dye Erythrosin B.

\section{RESULTS}

The results this figures show in the process of biodegradation of the dye Erythrosin B, alterations in the molecular structure of this dye, as well as, new products generated for the biodegradation.

\section{DISCUSSION}

A molecule is not a rigid association of atoms. It can compare a molecule to a system of balls with variable masses, corresponding to the molecule atoms, and springs of different lengths, corresponding to the chemical links of the molecule. There are two fundamental modes of molecule vibration: stretching, in which the distance between the atoms increase or decrease, but the atoms are at same linking axe, deformation, in which the position of the atom changes relating to the original linking axe (Dyer, 1969).
Form the FTIR spectra carried out with Neurospora crassa 74A, the control showed bands at 578, 666, 1036, 1376, 1425, 1654, 2924 and $3418 \mathrm{~cm}^{-1}$ (Fig. 6), which was a characteristic of the fungus, also determined by Bhanoori and Venkateswerlu, (2000) and Jesus, et al.,( 2002).

The analysis of biomass lecture in FTIR cultivated in diversified medium showed band at $2343 \mathrm{~cm}^{-1}$, witch was characteristic of the presence of $\mathrm{CO}_{2}$ was also confirmed by Orsini et. al. (2000) and Jesus (2002).

In the analyses of the Erythrosin B dye in UV-Vis spectrophotometer, in the original solution, the group kinolic showed peaks at 245 and $435 \mathrm{~nm}$ (Fig. 2 and 3). After $90 \mathrm{~h}$ the interaction the results showed that practically the bands were not more visible indicating a possible active site of an enzimatic modification (Fig. 4 and 5).

The carboxylic acid shows peaks at 200-205 $\mathrm{nm}$ (Fig. 2), being another possible modification since in the treated this band disappeared (Fig. 4). 


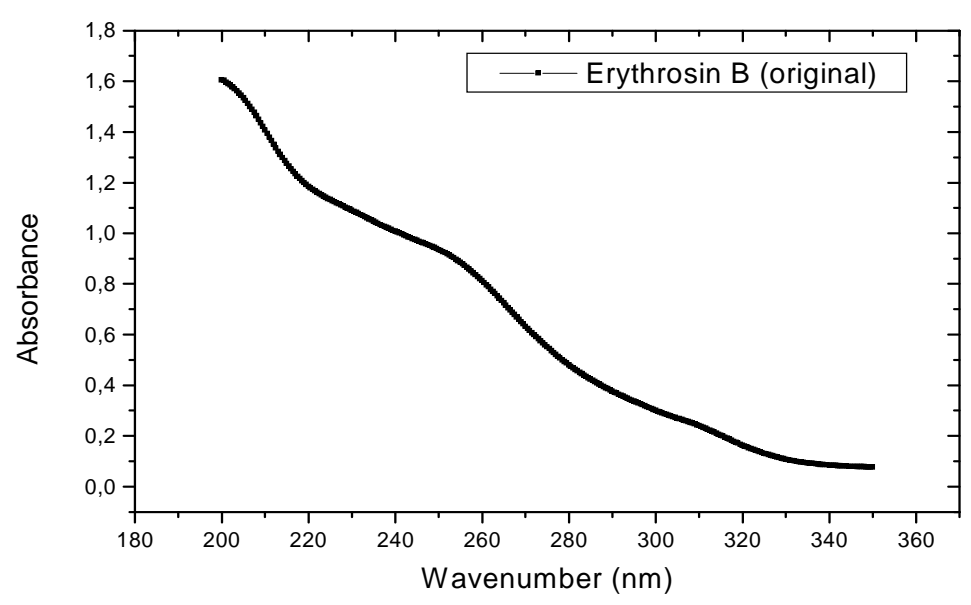

Figure 2 - Absorption spectra UV-Vis of the dye Erythrosin B original, at the range 180-350nm.

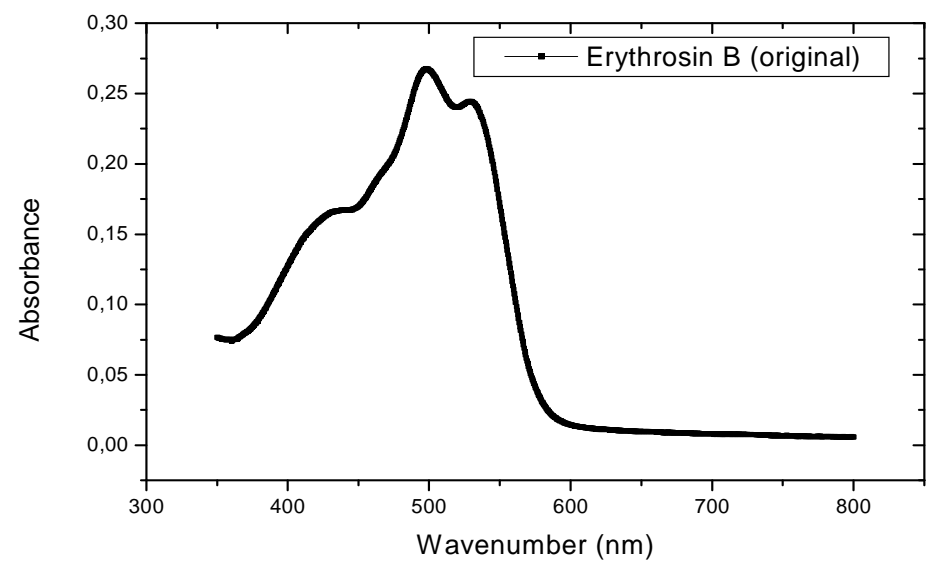

Figure 3 - Absorption spectra UV-Vis of the dye Erythrosin B original, at the range 350-800nm.

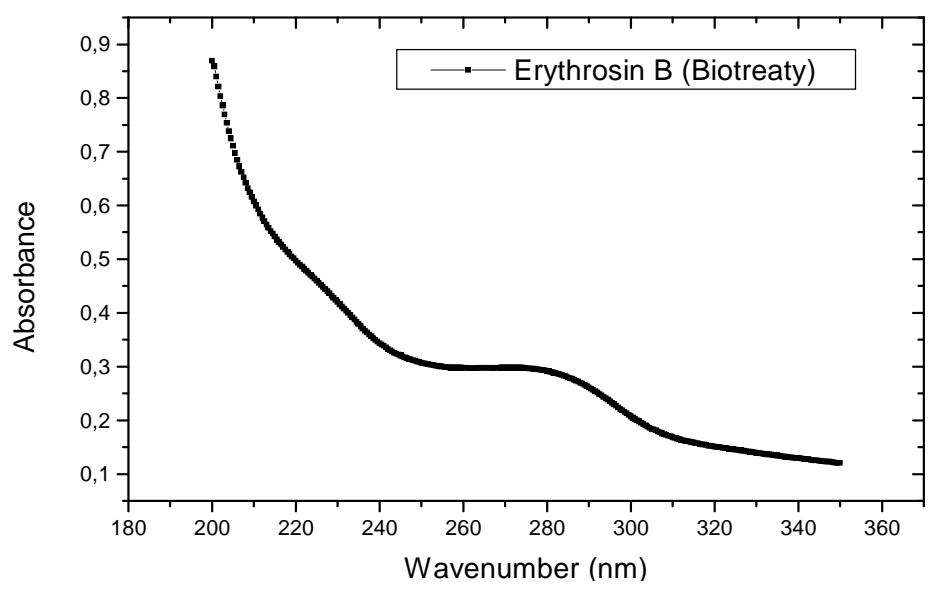

Figure 4 - Absorption spectra UV-Vis of the dye Erythrosin B original (after 90 hours of interaction), at the range $180-350 \mathrm{~nm}$. 


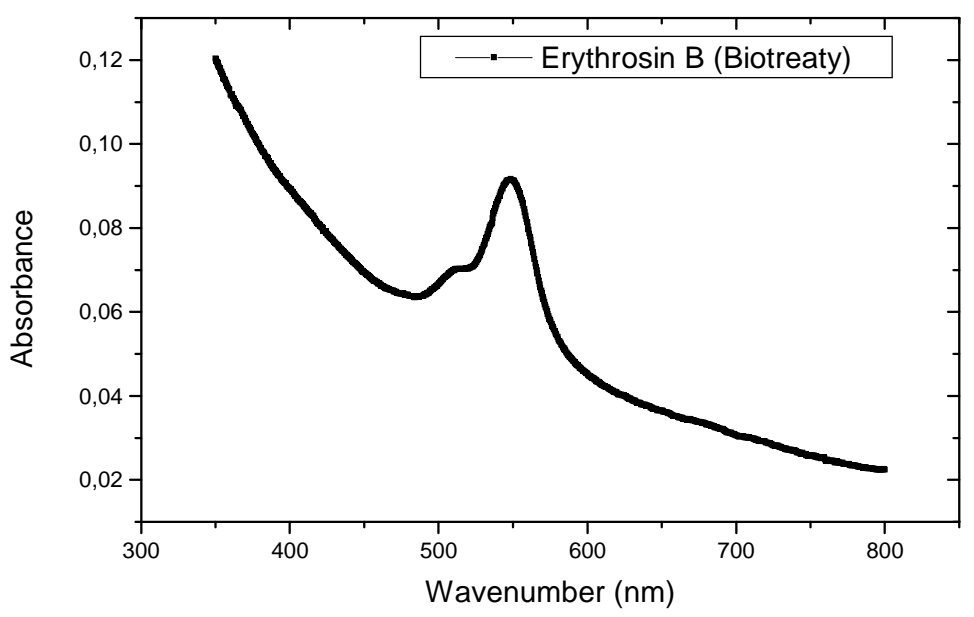

Figure 5 - Absorption spectra UV-Vis of the dye Erythrosin B biotreaty (after 90 hours of interaction), at the range $300-800 \mathrm{~nm}$.

FTIR spectra of the natural cell wall of the fungus compared with the one that was in contact with the dye, indicated that the Erythrosin B caused a increase in the signals, mainly between the regions
400 and $900 \mathrm{~cm}^{-1}$ and 1100 and $1750 \mathrm{~cm}^{1}$ (Fig. 6, 8 and 9), and an increase at 2750 and $3.450 \mathrm{~cm}^{1}$ after 2 and 90-h interaction, was also informed by Galichet et al., (2001).

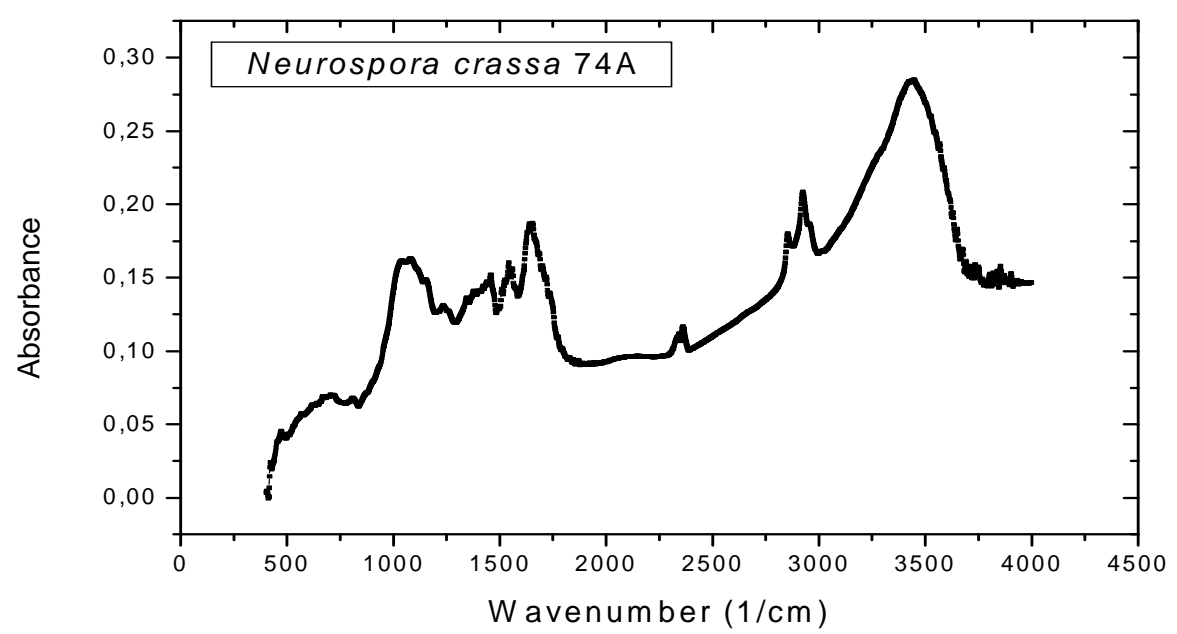

Figure 6 - FTIR cell walls spectra of $N$. crassa (1mg dry weight) isolated from control. 


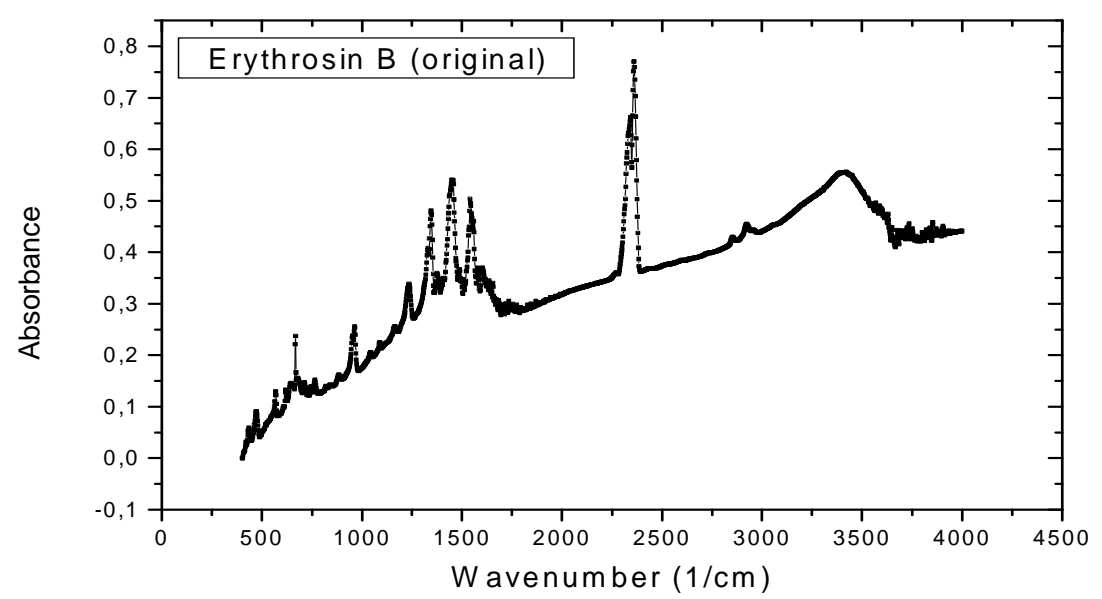

Figure 7 - Erythrosin B (1mg dry weight - after the mixture dye/KBr and subject to FTIR.

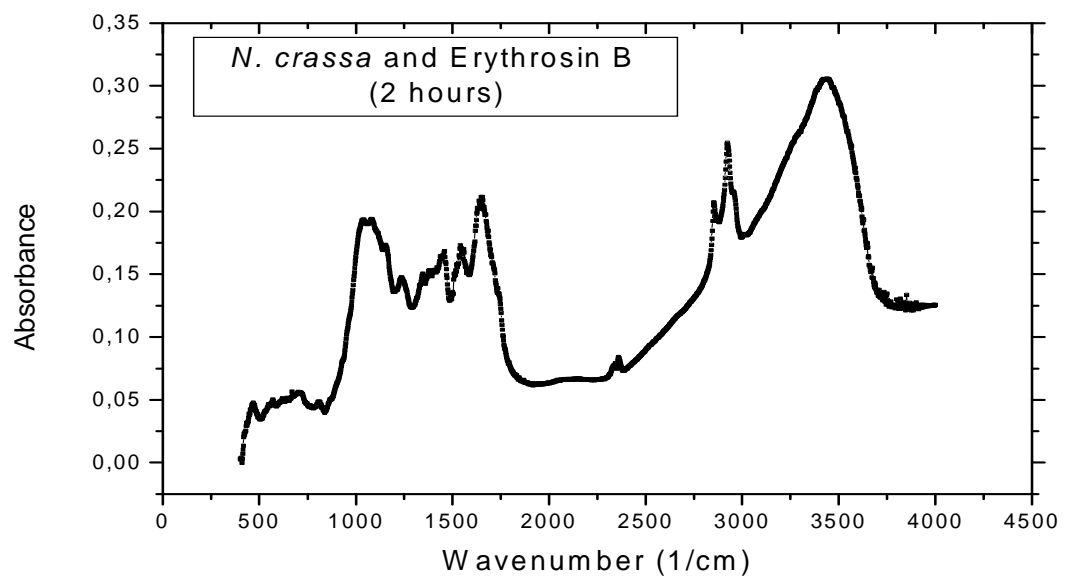

Figure 8 - FTIR cell walls spectra of $N$. crassa (1mg dry weight) and Erythrosin B mycelia after 2 hours of dye treatment were ground with $\mathrm{KBr}$.

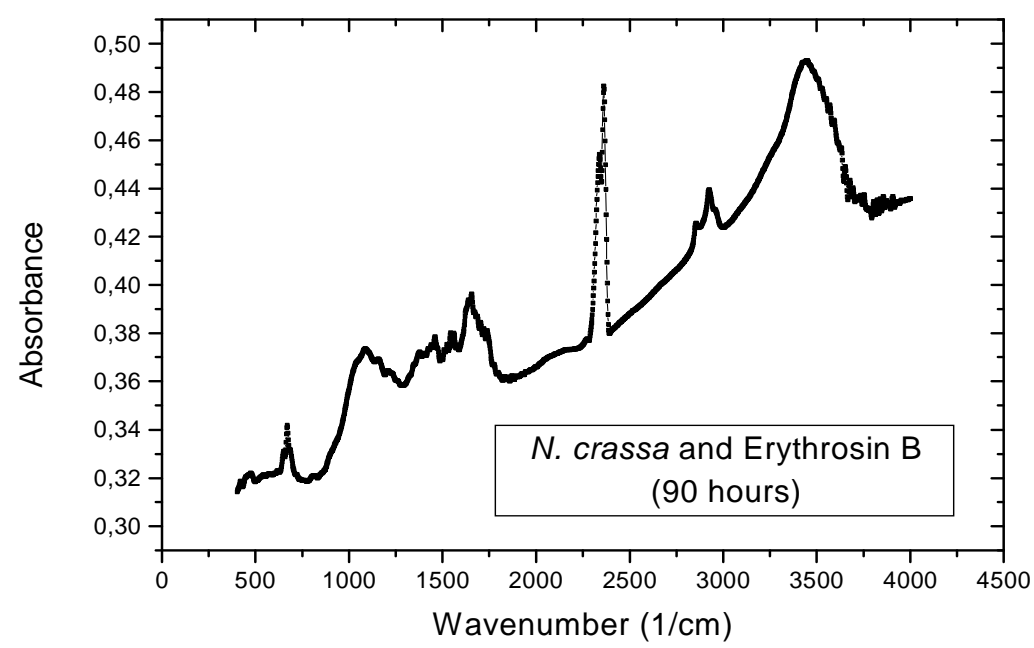

Figure 9 - FTIR spectra of cell walls of $N$. crassa (1mg dry weight) and Erythrosin B mycelia after 90 hours of dye treatment were ground with $\mathrm{KBr}$. 
In the FTIR spectra, Erythrosin B showed that aromatics nucleus mono and di halogenics strongly absorve in this region from 1350 to 1120 $\mathrm{cm}^{-1}$ probably these sites are occupied by biodegradation of the iodum (Fig. 7), after 2 and
90 hours the bands decrease significantly in this region (Fig. 10 and 11) In the kinolic nucleous $1690-1635 \mathrm{~cm}^{-1}$, this fact also occurred, this modification confirms an adaptation period dye/cell wall (Kamnev et al., 1997).

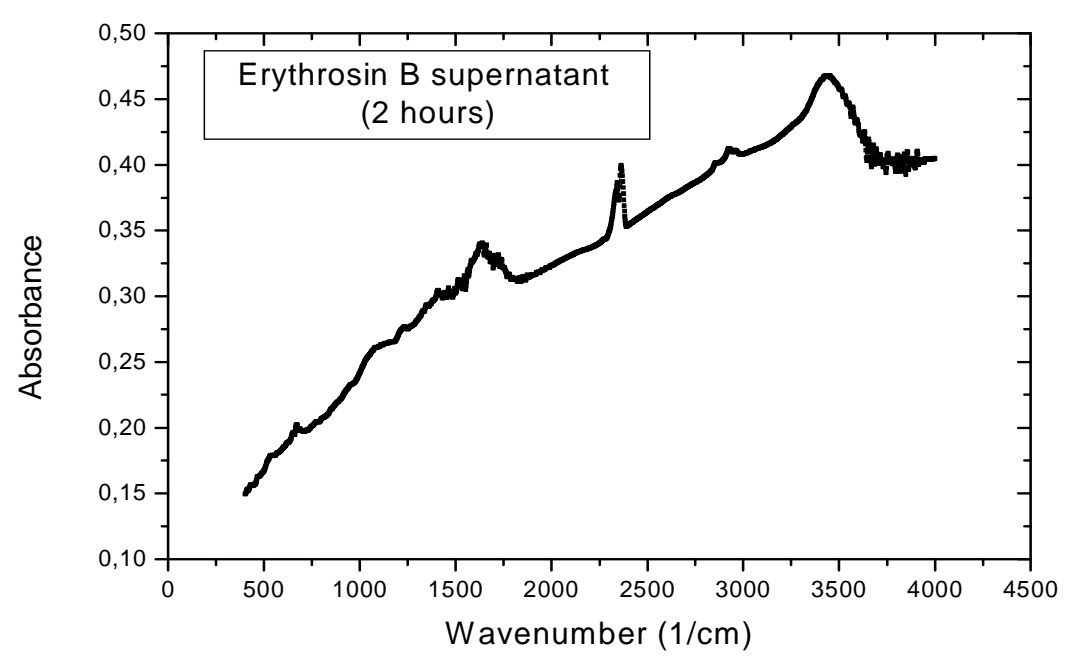

Figure 10 - FTIR spectra of Erythrosin B supernatant (1mg dry weight) after 2 hours of dye treatment were ground with $\mathrm{KBr}$.

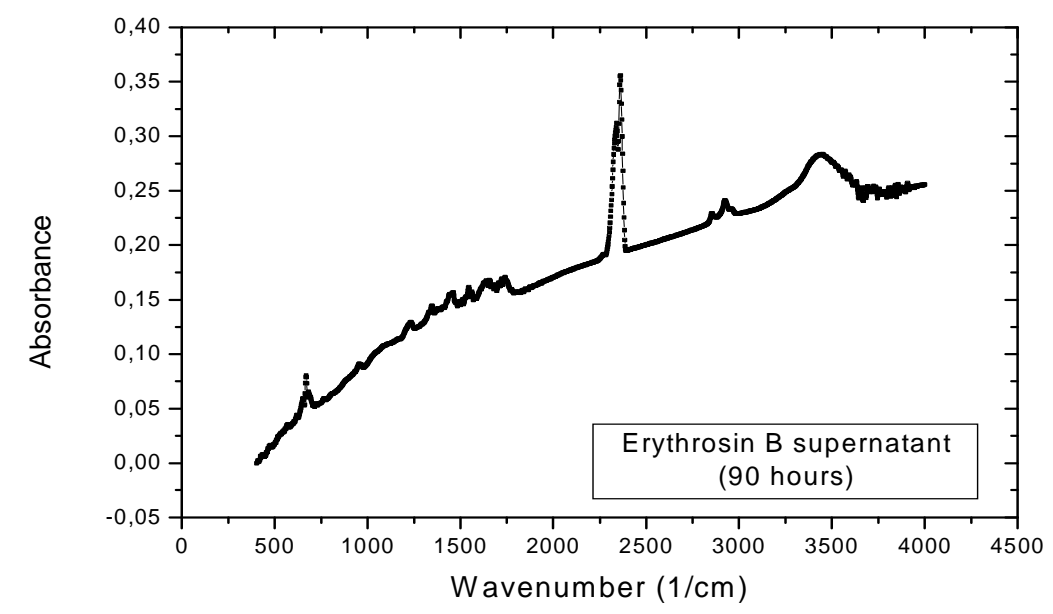

Figure 11 - FTIR spectra of Erythrosin B supernatant (1mg dry weight) after 90 hours of dye treatment were ground with $\mathrm{KBr}$.

\section{CONCLUSIONS}

Significant differences in the spectrum of UV-VIS were observed between the control and the supernatant. The FTIR spectra revealed modifications both in the cellular wall of $N$. crassa and Erythrosin B, supernatant fraction. Significant differences in the FTIR spectra were observed between the control (biomass) and the colored cell walls with 2 and 90-h contact. The main modified absorption bands were between 400 and $900 \mathrm{~cm}^{-1}$, and between 1100 and $1750 \mathrm{~cm}^{-1}$. Regarding Erythrosin supernatant significant modifications were observed between 400 and $1750 \mathrm{~cm}^{-1}$, being more pronounced at the contact time of $90 \mathrm{~h}$, in both cases. These data suggested that there was the 
possibility of biodegradation, and this was in proportion to the contact time dye with the fungus biomass.

\section{ACKNOWLEDGMENT}

Capes, CNPq, Fapesp and Fundunesp.

\section{RESUMO}

O presente trabalho utilizou formas paramorfogênicas de Neurospora crassa 74A linhagens, na remoção do corante "Erythrosin B". $\mathrm{O}$ fungo, induzido química e fisicamente em forma de "pellets", foi usado no estudo da biodegradação deste corante. A cultura fúngica foi crescida em meio contendo o corante, como única fonte de carbono por 2 e $90 \mathrm{~h}$ de interação. As paredes celulares foram isoladas por um processo de lavagem em água destilada e o micélio fresco foi secado por $12 \mathrm{~h}$ a $105^{\circ} \mathrm{C}$, e transformado num pó fino, e analisado em FTIR. O sobrenadante foi analisado através de espectrofotômetro UV-VIS e FTIR. Diferenças significativas no espectro UVVIS e no FTIR foram observadas entre o controle e o sobrenadante e entre o controle e as paredes coloridas de vermelho e em FTIR no tempo de 2 e $90 \mathrm{~h}$. Algumas bandas foram modificadas sugerindo a possibilidade de uma biodegradação enzimática em função do tempo de contato entre o corante e a biomassa fúngica.

\section{REFERENCES}

Azmi, W., Sani, R. J., Banerjee, U. C. (1998), Biodegradation of triphenylmryhane dyes. Enzyme and Microbiol Technology, 22, 185-191.

Bhanoori, M. e Venkateswerlu, G. (2000), In vivo chitin-cadmium complexation in cell wall of Neurospora crassa. Biochimica et Biophysica Acta, 1519, 21-28.

Borges, A.K.P.; Tauk-Tornisielo, S.M.; Domingos, R.N.; Angelis, D.F. de. (2008), Performance of the Constructed Wetland System for the Treatment of Water from the Corumbataí River. Brazilian Archives biology and Technology, 51 (6), 1279-1286,

Chu, W. Dye Removal from Textile Dye (2001), Wastewater using recycled Alum Sludge. Water Research. 35 (13), 3147-3152.
Dayer, J.R. (1969), Aplicações da espectroscopia de absorção aos compostos orgânicos, São Paulo: Ed. Edgard Blücher LTDA, 155p.

Espíndola, L. H. S., Espíndola, F. S., Freitas, G. R., Brandeburgo, M. A. M. (2007), Biodegradation of Red 40 by the Mushroom Pleorotus sp florida. Biosci. J. 23 (3), 90-93.

Lefebvre, D. D., Chenaux, P., Edwards, M. (2005), Dye Degradation by fungi: An Exercise in Apllied Science for Biology Students. Bioscene, 31 (3), 13-16.

Galechet, A., Sockalingum, G. D., Belarbi, A., Manfait, M. (2001), FTIR spectroscopic analysis of Saccharomyces cerevisiae cell wall: study of an anomalous strain exihibiting a pink-colored cell phenotype. FEMS Microbiology Letters, 197, 179186.

Jesus, G. J., Franchetti, S. M. M., Corso, C. R. (2002), Estudo da biodegradação de compostos azóicos de efluentes da indústria têxtil. Arquivos Instituto Biológico, São Paulo, 69, 159-162,.

Kammev, A., A., Ristié, M., Antonyuk, L. P., Chernychev, A V., Ignatov, V. V. (1997), Fourier transform infrared spectroscop study of intact cells on the nitrogen-fixing bacterium Azozpirillum brasiliense. Journal of Molecular Structure, 408-409, 201-205.

Kirby, N.; Marchant, R.; Mcmullan, G. (2000), "Decolourisation of synthetic textile dyes by Phlebia tremellosa” Fems Microbiology Letters, 188, 93-96.

Marcanti-Contato, I., Corso, C. R., Oliveira, J.E. (1997), Induction of physical paramorphogenesis in Aspergillus sp. Revista de Microbiologia , 28, 65-67.

Orsini, F.; Ami, D.; Villa, A. M.; Sala, G.; Bellotti, M.G.; Doglia, S. M. (2000), FT-IR microspectroscopy for microbiological studies. Journal of Microbiological Methods, 42, 17-27.

Santos, I.R.; Costa, R.C.; Freitas, U.; Fillmann, G. (2008), Influence of effluents from a wastewater treatment plant on nutrient distribution in a coastal creek from southern Brazilian Archives Biology and Technology, 51 (1), 153-162.

Suresh, K. e Subramanyam, C. P. (1998), Polyphenols are involved in copper binding to cell walls of Neurospora crassa. Journal of Inorganic Biochemistry, 69, 209-215.

Tatum, E. I.; Barratt, R. W.; Cutter, V .M.-Jr. (1949), "Chemical induction of colonial paramorphs in Neurospora crassa and Syncephalastrum”. Science. 109, 509-511.

Wang, Y., YU, J. (1998), Adsorption and degradation of synthetic dyes on the mycelium of Trametes versicolor. Water Science Technology

Received: February 18, 2008; Revised: December 08, 2008; Accepted: November 10, 2009. 